\title{
Size at maturity of the Pacific sharpnose shark Rhizoprionodon longurio in the Gulf of California, Mexico
}

\section{Talla de madurez del tiburón bironche Rhizoprionodon longurio en el Golfo de California, México}

\author{
D Corro-Espinosa ${ }^{1}$, JF Márquez-Farías², A Muhlia-Melo ${ }^{3 *}$ \\ ${ }^{1}$ Centro Regional de Investigaciones Pesqueras de Mazatlán, Instituto Nacional de Pesca, SAGARPA, \\ Calzada Sábalo-Cerritos s/n, CP 82010, Mazatlán, Sinaloa, México. \\ ${ }^{2}$ Facultad de Ciencias del Mar, Universidad Autónoma de Sinaloa, Paseo Claussen s/n, CP 82000, Mazatlán, \\ Sinaloa, México. \\ ${ }^{3}$ Centro de Investigaciones Biológicas del Noroeste, S.C., Mar Bermejo 195, Playa Palo de Santa Rita, \\ CP 23090, La Paz, Baja California Sur, México.
}

* Corresponding author. E-mail: amuhlia04@cibnor.mx

\begin{abstract}
We report on the proportion of maturity stages as a function of size of the Pacific sharpnose shark Rhizoprionodon longurio. Based on the development of internal and external organs, males and females were classified as immature or mature. A logistic model was fitted to develop a maturity curve to estimate the length at which $50 \%$ of the individuals are mature $\left(L_{50 \%}\right)$. This species has an annual reproductive cycle and its birthing season is from April to July, with June as the main month. For males, $L_{50 \%}=100.61 \mathrm{~cm}$ total length (TL) and $\Phi=2.57$, and for females, $L_{50 \%}=92.9 \mathrm{~cm}$ TL and $\Phi=1.08$. For pregnant females, $L_{50 \%}=106.4 \mathrm{~cm}$ TL and $\Phi=6.11$. The maturity curves obtained in the present study can be used in demographic studies to produce more accurate forecasts of the population reproductive rate and thus develop fishery management measures for this species.
\end{abstract}

Key words: Rhizoprionodon longurio, Gulf of California, reproduction, maturity curve.

RESUMEN. Se presenta información sobre la proporción de estadios de madurez del tiburón bironche Rhizoprionodon longurio en función de la longitud. Con base en el desarrollo de los órganos internos y externos, los machos y las hembras se clasificaron como inmaduros y maduros. Se ajustó un modelo logístico para obtener la curva de madurez sexual y estimar la longitud a la cual el 50\% de los individuos alcanzó la madurez sexual $\left(L_{50 \%}\right)$. La especie se reproduce anualmente y la temporada de nacimiento es de abril a julio, siendo junio el mes principal. Para machos, $L_{50 \%}=100.61 \mathrm{~cm}$ longitud total (LT) y $\Phi=2.57$, y para hembras, $L_{50 \%}=92.9 \mathrm{~cm} \mathrm{LT} \mathrm{y} \Phi=1.08$. Para las hembras preñadas, $L_{50 \%}=$ $106.4 \mathrm{~cm}$ LT y $\Phi=6.11$. Las curvas de madurez obtenidas en el presente estudio pueden usarse en estudios demográficos para obtener pronósticos más precisos de la tasa reproductiva poblacional que permitan recomendar medidas de manejo pesquero para esta especie.

Palabras clave: Rhizoprionodon longurio, Golfo de California, reproducción, curva de madurez.

\section{INTRODUCTION}

The Pacific sharpnose shark Rhizoprionodon longurio (Jordan and Gilbert 1882) (family Carcharhinidae) is a small shark that inhabits coastal waters of the eastern Pacific Ocean, from southern California to Peru (Compagno 1984). It is found on muddy bottoms and its diet consists of demersal species (Márquez-Farías et al. 2005). In Mexico, this species is exploited commercially by coastal communities (mainly artisanal fleets) from the Gulf of California to Puerto Madero, Chiapas. Rhizoprionodon longurio migrates seasonally, reaching the northernmost part of the Gulf of California. This seasonal mobility and the distinct population size and sex structure of this species make it difficult to understand its life cycle. Proper management of this fishery

\section{INTRODUCCIÓN}

El tiburón bironche Rhizoprionodon longurio (Jordan y Gilbert 1882) (familia Carcharhinidae) es una especie de tamaño pequeño que habita aguas costeras del Océano Pacífico oriental y se distribuye del sur de California a Perú (Compagno 1984). Es una especie que frecuenta zonas de fondo fangoso y basa su dieta en especies de hábitos demersales (Márquez-Farías et al. 2005). En México, esta especie es explotada comercialmente por las comunidades costeras (principalmente por flotas artesanales) desde el Golfo de California hasta Puerto Madero, Chiapas. Rhizoprionodon longurio migra estacionalmente, penetrando hasta el área norte del Golfo de California. Esta movilidad estacional y la diferente estructura poblacional por tallas y sexos dificultan 
resource requires biological information of reproductive, age and growth, and demographic parameters.

Sharks belong to a group of species (K-strategists) whose biological profile includes low fecundity, long gestation period, slow individual growth, and late attainment of sexual maturity, resulting in discrete to reduced population growth, compared with other marine fish (Musick 1999). Because of these life history characteristics, they are excluded as candidates for sustainable exploitation (Holden 1973, 1974). On the other hand, the lack of catch and effort time series and of exploitation patterns for most elasmobranchs has hindered the application of quantitative stock assessment models (Anderson 1990). Demographic techniques have thus been proposed to evaluate these populations and determine the productivity of the species, based on age-specific survival and reproductive rates (Cortés 1998, 2004).

Unlike the large-size sharks, the species of the genus Rhizoprionodon have a fast growth rate and mature sexually at a relatively early age (Simpfendorfer 1993, Loefer and Sedberry 2003, Lessa et al. 2009). Demographic studies have shown that $R$. taylori has a high intrinsic rate of population increase (Simpfendorfer 1999), whereas $R$. terraenovae has a relatively low intrinsic rate (Márquez-Farías and CastilloGéniz 1998, Cortés 1995) and exhibits high vulnerability to fishing effort despite being a fast-growing shark (Cortés 1998).

Few studies have been conducted on the biology and ecology of $R$. longurio. Márquez-Farías et al. (2005) reported on the reproductive biology of this species, but detailed information on the proportion of mature individuals per size class is lacking. The proportion of mature individuals is a significant element of demographic studies, which are based on the age structure. Incorporating a maturity curve allows a more reliable prediction of population reproduction rates. In the present analysis, the maturity of $R$. longurio is determined as a function of shark length, information that can be used to regulate the exploitation of this fishery resource.

\section{MATERIAL AND METHODS}

During the period 2005-2009, a total of 590 individuals of $R$. longurio were examined from December to May in fishing camps on the coast of Sinaloa and Sonora, Mexico (fig. 1). The specimens were obtained from the commercial landings of artisanal fleets operating in coastal waters off Sonora, Sinaloa and Nayarit. The artisanal fishing vessels are, on average, $7 \mathrm{~m}$ long and have an autonomy of two days. Shark fishing is highly seasonal, occurring from November to July, with greater activity from January to March. Gillnets and longlines are deployed at depths around 30 fathoms. Fishing is variable and depends on the target species. In the fishery targeting $R$. longurio, the fishing gear remained in the water for an average of $12 \mathrm{~h}$. conocer su ciclo de vida. El manejo de este recurso pesquero requiere información biológica de parámetros reproductivos, de edad y crecimiento, y demográficos.

Los tiburones pertenecen a un grupo de especies con perfil biológico (estratega $\mathrm{K}$ ) que incluye una baja fecundidad, largos periodos de gestación, crecimiento individual lento y maduración sexual tardía, lo que resulta en un crecimiento poblacional de discreto a reducido, comparado con otros peces marinos (Musick 1999). Debido a estas características en su historia de vida natural, se han excluido como candidatos de explotación sostenible (Holden 1973, 1974). Por otra parte, la carencia de series de tiempo de captura y esfuerzo y de los patrones de explotación de la mayoría de los elasmobranquios ha imposibilitado la aplicación de modelos cuantitativos de evaluación de poblaciones (Anderson 1990). Alternativamente, se han propuesto técnicas demográficas para evaluar estas poblaciones y determinar la productividad de las especies, con base en las tasas específicas de edad de supervivencia y reproducción (Cortés 1998, 2004).

A diferencia de los tiburones de talla grande, las especies del género Rhizoprionodon tienen un rápido crecimiento $\mathrm{y}$ maduran sexualmente a una edad relativamente temprana (Simpfendorfer 1993, Loefer y Sedberry 2003, Lessa et al. 2009). Estudios demográficos han demostrado que R. taylori presenta una tasa intrínseca de incremento poblacional alta (Simpfendorfer 1999), pero en $R$. terraenovae esta tasa es relativamente baja (Márquez-Farías y Castillo-Géniz 1998, Cortés 1995) y exhibe una alta vulnerabilidad a la presión pesquera a pesar de ser un tiburón de rápido crecimiento (Cortés 1998).

Los estudios sobre la biología y ecología de $R$. longurio son escasos. Márquez-Farías et al. (2005) proporcionaron información sobre su biología reproductiva; no obstante, no existe información detallada de la proporción de individuos en condición de madurez en cualquier tamaño. La proporción de individuos maduros es un elemento significativo en los estudios demográficos, los cuales se basan en la estructura de edades. La incorporación de la curva de madurez permite un pronóstico más confiable de las tasas reproductivas poblacionales. En el presente análisis se determina la madurez de $R$. longurio en función de la proporción de longitudes de los tiburones, información que puede ser utilizada para la regulación de sus capturas en la pesquería.

\section{MATERIAL Y MÉTODOS}

En el periodo 2005-2009, se examinaron 590 individuos de diciembre a mayo en campos pesqueros de la costa de Sinaloa y Sonora, México (fig. 1). Los individuos de $R$. longurio se obtuvieron de las descargas comerciales de la pesca ribereña, cuyas flotas incluyeron como zona de pesca, además de Sinaloa y Sonora, las aguas frente a las costas de Nayarit. Las embarcaciones utilizadas por estas flotas miden, en promedio, $7 \mathrm{~m}$ de eslora y tienen autonomía para 


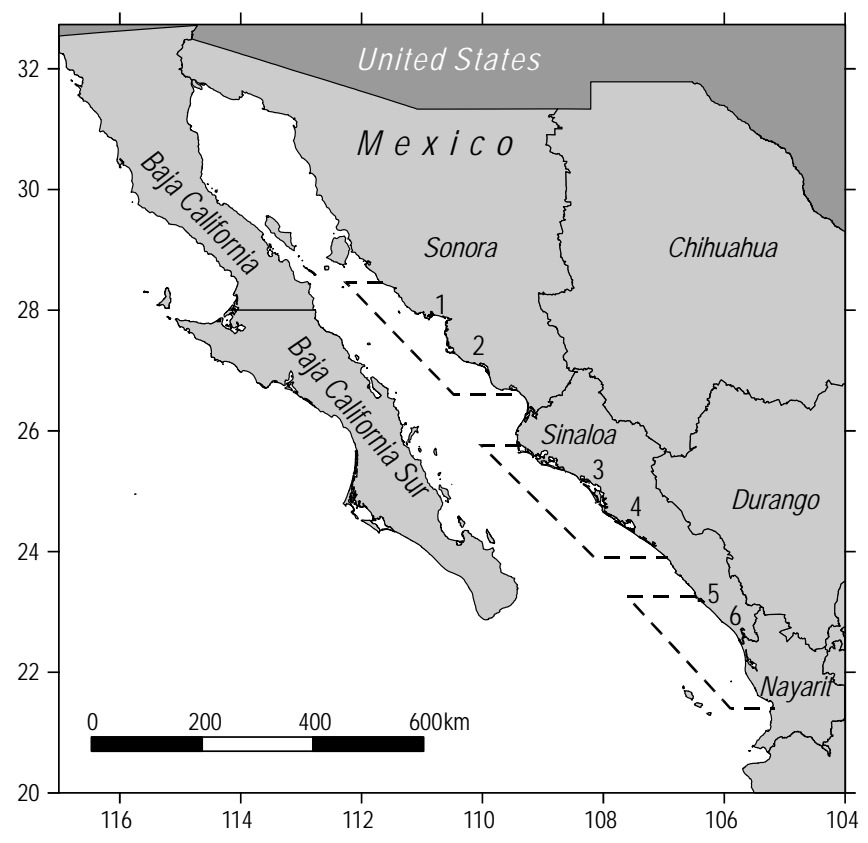

Figure 1. Study area. Fishing camps sampled (numbers) and areas assigned to the local fishing fleets (dashed lines).

Figura 1. Área de estudio. Campos pesqueros muestreados (números) y áreas asignadas a las flotas pesqueras (líneas discontinuas).

Flexed total length $\left(\mathrm{TL}_{\mathrm{flex}}\right)$, the straight-line distance between the tip of the snout and the distal tip of the caudal fin aligned with the body midline, was recorded in millimeters (Francis and Duffy 2005). In this study, $\mathrm{TL}_{\text {flex }}$ will be referred to as TL except when it is compared to natural total length $\left(\mathrm{TL}_{\text {nat }}\right)$, the straight-line distance between the tip of the snout and the distal tip of the caudal fin in a natural position (Compagno 1984). After measuring, the specimens were sexed and eviscerated to analyze the reproductive condition, and neonates were examined for the presence of an umbilical scar, following the criteria proposed by Abdel-Aziz et al. (1993) and Goldman (2004).

\section{Sexual maturity}

The stages of sexual maturity in $R$. longurio were assigned according to Goldman (2004) and Márquez-Farías et al. (2005). For males, sexual maturity was determined based on the level of calcification and capacity of rotation of the claspers, as well as the presence or absence of semen, and four stages were used: neonate (0), juvenile (1), subadult (2), and adult (3). For females, sexual maturity was assessed based on oocyte development, the level of the nidamentary gland, and the presence of embryos, and six stages were used: neonate (0), juvenile (1), subadult (2), adult (3), pregnant (4), and postpartum (5). In both males and females, the first three stages $(0-2)$ corresponded to immature individuals and the remaining stages to mature individuals. dos días. El régimen de pesca de tiburón es muy estacional; se desarrolla de noviembre a julio, con mayor actividad de enero a marzo. Se utilizan redes de enmalle y palangres o cimbras, las cuales se emplean a una profundidad promedio de 30 brazas. La operación de pesca es variable y depende de la especie objetivo. En la pesca dirigida a $R$. longurio el arte de pesca en el agua presentó un promedio de duración de $12 \mathrm{~h}$.

La longitud total flexionada $\left(\mathrm{LT}_{\text {flex }}\right)$, distancia en línea recta entre la punta del hocico y el extremo distal de la aleta caudal colocada en línea recta con respecto al eje del cuerpo, se registró en milímetros (Francis y Duffy 2005). En el presente trabajo se hace referencia a la $\mathrm{LT}_{\text {flex }}$ como LT, excepto cuando ésta es comparada con la longitud total natural ( $\left.\mathrm{LT}_{\text {nat }}\right)$, que es la distancia en línea recta entre la punta del hocico y el extremo distal de la aleta caudal en posición natural (Compagno 1984). Una vez medidos, se distinguió el sexo de los ejemplares y éstos se evisceraron para analizar su condición reproductiva. En los organismos recién nacidos se registró la presencia de la cicatriz umbilical, siguiendo criterios sugeridos por Abdel-Aziz et al. (1993) y Goldman (2004).

\section{Madurez sexual}

Para asignar las fases o estadios de madurez sexual de $R$. longurio se siguieron los criterios de Goldman (2004) y Márquez-Farías et al. (2005). En los machos esta condición se estimó mediante la observación de la calcificación de los gonopterigios y de su capacidad rotatoria, así como la presencia o ausencia de semen, y se utilizaron cuatro estadios: neonato (0), joven (1), subadulto (2) y adulto (3). En las hembras, la madurez sexual se determinó con base en la observación del estado de desarrollo de los ovocitos, la glándula nidamentaria y la presencia de embriones, y se utilizaron seis estadios: neonato (0), joven (1), subadulto (2), adulto (3), preñez (4) y post partum (5). En machos y hembras las tres primeras fases (0-2) correspondieron a individuos inmaduros y las restantes a los individuos maduros.

\section{Proporción de madurez}

Una vez que se asignaron los estadios de madurez a cada individuo, los datos se tabularon por tamaños de clase. Se ajustó la función logística a los datos binomiales de madurez $(0=$ inmaduro, 1 = maduro $)$ mediante la siguiente fórmula:

$$
M L=\left(\frac{1}{1+\exp \left(-\left(L T-L_{50 \%}\right) / \Phi\right)}\right)
$$

donde $M L$ es la proporción de individuos maduros a la LT (cm), $L_{50 \%}$ es la longitud a la que el $50 \%$ de los individuos ha alcanzado la madurez sexual (tamaño medio de madurez) y $\Phi$ es la pendiente de la curva. La diferencia entre esta relación y los sexos se probó mediante la aplicación de un 


\section{Proportion of maturity}

After assigning a maturity stage to each individual, the data were tabulated by size class. The logistic function was fitted to the binomial maturity data $(0=$ immature, $1=$ mature) using the following equation:

$$
M L=\left(\frac{1}{1+\exp \left(-\left(T L-L_{50 \%}\right) / \Phi\right)}\right)
$$

where $M L$ is the proportion of mature individuals at TL $(\mathrm{cm})$, $L_{50 \%}$ is the length at which $50 \%$ of the individuals have attained sexual maturity (mean maturity size), and $\Phi$ is the slope of the curve. The difference between this relation and the sexes was tested by applying an analysis of covariance (ANCOVA). The parameters and their confidence intervals were estimated by binary regression and probit analysis using the Minitab 16.0 software.

\section{RESULTS}

\section{Size distribution}

Significant statistical differences were found between male and female length frequencies (analysis of variance, $P<0.0005$; Mann-Whitney, Wilcoxon). The mean size for males was $90.3 \mathrm{~cm} \mathrm{TL}$ (minimum $=40.0 \mathrm{~cm} \mathrm{TL}$, maximum $=$ $112.7 \mathrm{~cm} \mathrm{TL}, n=283$ ) and for females, $97.81 \mathrm{~cm} \mathrm{TL}$ $($ minimum $=41.0 \mathrm{~cm} \mathrm{TL}$, maximum $=129.0 \mathrm{~cm} \mathrm{TL}, n=$ 307). For both sexes, the length frequency distribution showed two modes (fig. 2): for males, at 75 and $100 \mathrm{~cm} \mathrm{TL}$ corresponding to juveniles and larger individuals, respectively; and for females, at 95 and $115 \mathrm{~cm}$ TL corresponding to large individuals.

\section{Maturity stages by length}

The population size structure, as a function of the maturity stages, showed a pattern with adult individuals of a larger size than juveniles (fig. 3, table 1). The proportion of males by maturity stage was reduced for neonates and about a third of the total for the ramaining stages (table 2). A rapid increase in length was evident when comparing the neonate and juvenile stages (fig. 3). The juvenile, subadult, and adult stages showed overlapping sizes, indicating a phase of slow growth. On combining the sizes in a binary format (fig. 4), a predominance of immature over mature individuals $(69 \%$ vs $30 \%$, respectively) was observed. The mean size of immature males was $84.2 \mathrm{~cm} \mathrm{TL}$ and of mature males, $103.9 \mathrm{~cm} \mathrm{TL}$.

The proportion of females by maturity stage was similar to that of males only in the case of neonates. The proportion of juvenile, subadult, adult, pregnant, and postpartum females was $23.1 \%, 8.8 \%, 10.5 \%, 39.8 \%$, and $16.2 \%$, respectively (table 2). Unlike the males, there was a predominance of mature over immature individuals $(66.5 \%$ vs $33.5 \%$, análisis de covarianza (ANCOVA). La estimación de los parámetros y sus intervalos de confianza se obtuvieron utilizando una regresión binaria y las rutinas de análisis probit del software Minitab 16.0.

\section{RESUltados}

\section{Distribución de tallas}

Se encontraron diferencias estadísticamente significativas entre las frecuencias de longitud de machos y hembras (análisis de varianza, $P<0.0005$; Mann-Whitney, Wilcoxon). La talla media de los machos fue de $90.3 \mathrm{~cm}$ LT (mínima $=$ $40.0 \mathrm{~cm} \mathrm{LT}$, máxima $=112.7 \mathrm{~cm} \mathrm{LT,} n=283$ ) y la de las hembras fue $97.81 \mathrm{~cm} \mathrm{LT} \mathrm{(mínima}=41.0 \mathrm{~cm} \mathrm{LT}$, máxima $=$ $129.0 \mathrm{~cm} \mathrm{LT}, n=307)$. En ambos sexos la distribución de las frecuencias de longitud mostró dos modas (fig. 2). Para los machos, las modas se ubicaron a los 75 y $100 \mathrm{~cm} \mathrm{LT,} \mathrm{y}$ correspondieron a jóvenes e individuos más grandes, respectivamente. Para las hembras, las modas se ubicaron a los $95 \mathrm{y}$ $115 \mathrm{~cm} \mathrm{LT}$, correspondiendo a individuos grandes.

\section{Estadios de madurez por longitud}

La estructura de la población, en función de los estadios de madurez, mostró un patrón con individuos adultos de mayor tamaño que los jóvenes (fig. 3, tabla 1). La proporción de individuos machos por estadio de madurez fue reducida para neonatos y muy próxima a un tercio del total para el resto de los estadios (tabla 2). Fue evidente una fase de incremento rápido en longitud cuando se compararon los tamaños de los estadios neonato y joven (fig. 3). Los estadios joven, subadulto y adulto mostraron tallas que se sobreponen entre sí, indicando una fase de lento crecimiento. Al combinar las tallas en un formato binario (fig. 4) se mostró la dominancia de los individuos inmaduros sobre los maduros $(69 \%$ vs $30 \%$, respectivamente). La talla media de los machos inmaduros fue de $84.2 \mathrm{~cm}$ LT y para los machos maduros, $103.9 \mathrm{~cm} \mathrm{LT}$.

En las hembras la proporción de individuos por estadio de madurez fue similar a la de los machos únicamente en los neonatos. La proporción de hembras jóvenes, subadultas, adultas, preñadas y en post partum fue de $23.1 \%, 8.8 \%$ $10.5 \%, 39.8 \%$ y $16.2 \%$, respectivamente (tabla 2 ). Contrario a los machos, en el tamaño de muestra de los datos combinados dominaron las hembras maduras frente a las inmaduras (66.5\% vs $33.5 \%$, respectivamente). La talla media de las hembras inmaduras fue $76.4 \mathrm{~cm} \mathrm{LT}$ y para las hembras maduras, $108.6 \mathrm{~cm}$ LT (fig. 4).

\section{Proporción de estadios de madurez y maternidad a la longitud}

La regresión logística binaria mostró diferencias estadísticamente significativas entre sexos en las ojivas de madurez (ANCOVA, $P<0.001$ ); por lo tanto, los parámetros de la 
respectively). The mean size of immature females was $76.4 \mathrm{~cm}$ TL and of mature females, $108.6 \mathrm{~cm}$ TL (fig. 4).

\section{Proportion of maturity and maternity stages at length}

The binary logistic regression showed significant statistical differences in the maturity ogives between sexes (ANCOVA, $P<0.001$ ); hence, the parameters in the logistic function were estimated separately. The equation that described the proportion of mature males was:

$$
M L=\left(\frac{1}{1+\exp (-(T L-100.61) / 2.57)}\right)
$$

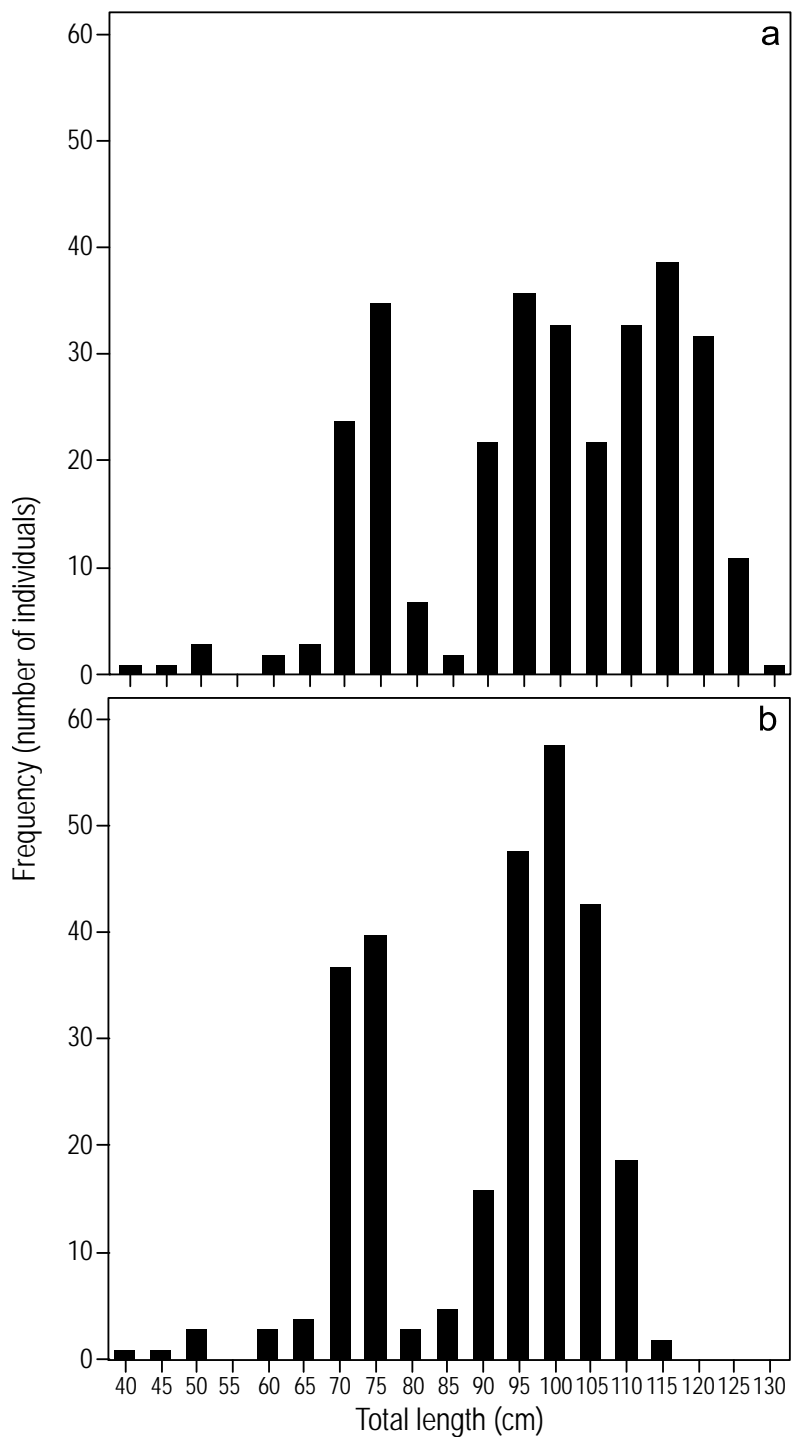

Figure 2. Length frequency distribution of (a) female and (b) male Rhizoprionodon longurio.

Figura 2. Distribución de frecuencias de longitud de (a) hembras y (b) machos de Rhizoprionodon longurio. función logística se estimaron por separado. La ecuación que describió la proporción de los machos maduros fue la siguiente:

$$
M L=\left(\frac{1}{1+\exp (-(L T-100.61) / 2.57)}\right)
$$

El intervalo de confianza de $95 \%$ osciló entre 99.6 y $101.6 \mathrm{~cm}$ LT para $L_{50 \%}$ y de 1.94 a 3.38 para $\Phi$ (fig. 5). La función logística para la proporción de hembras maduras se describió mediante la siguiente formula:

$$
M L=\left(\frac{1}{1+\exp (-(L T-92.9) / 1.08)}\right)
$$

El intervalo de confianza de 95\% varió de 91.97 a $93.84 \mathrm{~cm}$ LT para $L_{50 \%}$ y de 0.699 a 1.67 para $\Phi$ (fig. 5).

La función logística para las hembras que describió la proporción de longitud a la maternidad fue la siguiente:

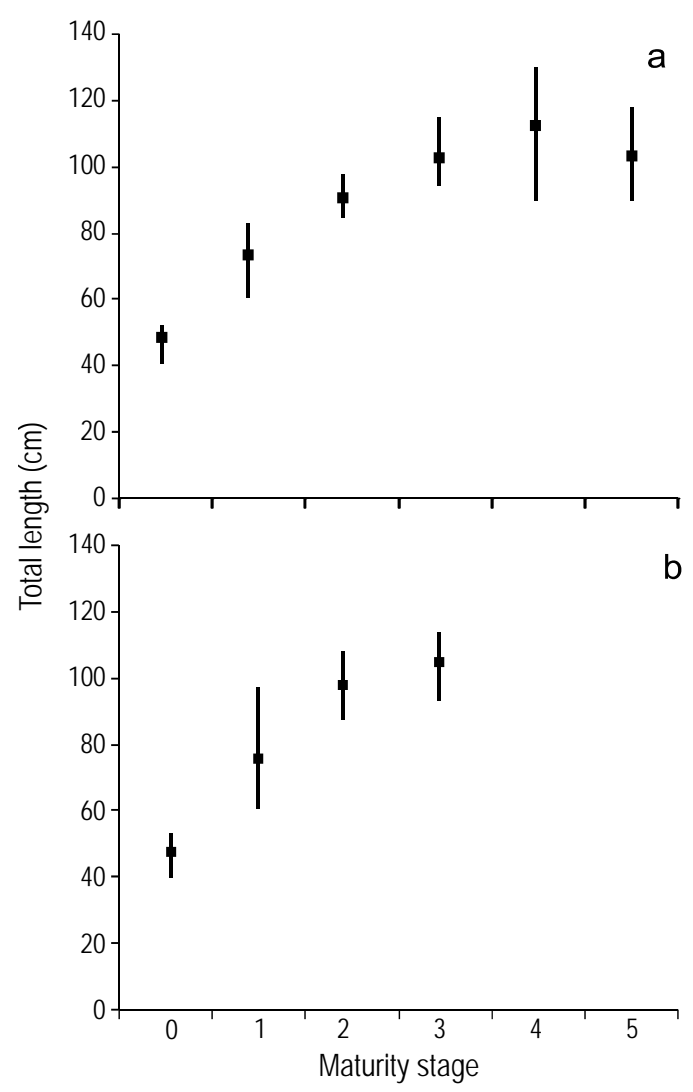

Figure 3. Size structure by maturity stage of (a) female and (b) male Rhizoprionodon longurio in the Gulf of California. Figura 3. Estructura de tallas por estadio de madurez de (a) hembras y (b) machos de Rhizoprionodon longurio en el Golfo de California. 


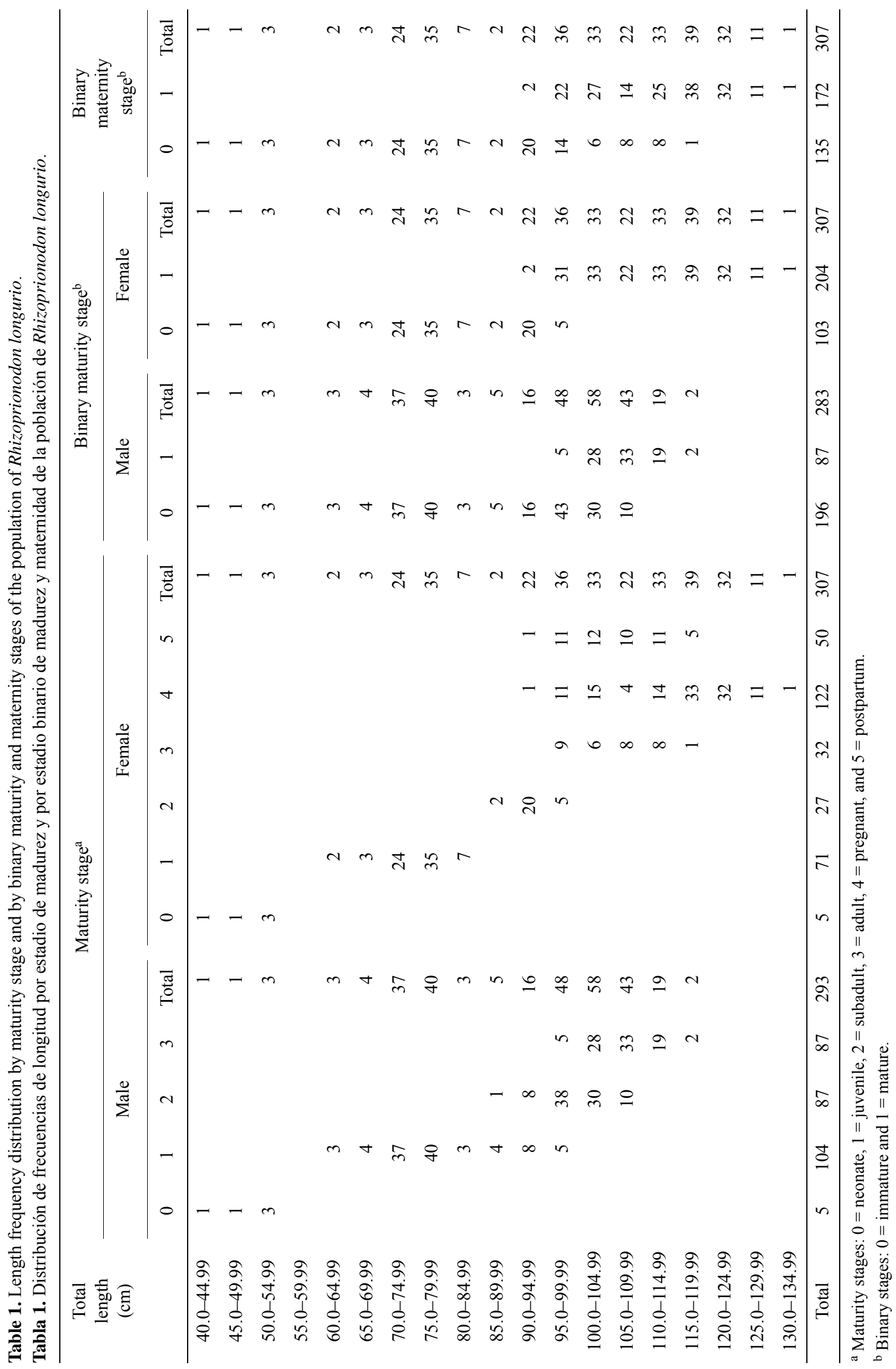


The $95 \%$ confidence interval ranged from 99.6 to $101.6 \mathrm{~cm}$ TL for $L_{50 \%}$ and from 1.94 to 3.38 for $\Phi$ (fig. 5). The logistic function for the proportion of mature famales was:

$$
M L=\left(\frac{1}{1+\exp (-(T L-92.9) / 1.08)}\right)
$$

The $95 \%$ confidence interval ranged from 91.97 to $93.84 \mathrm{~cm}$ TL for $L_{50 \%}$ and from 0.699 to 1.67 for $\Phi$ (fig. 5).

The logistic function for females that described the proportion of maternity length was:

$$
M L=\left(\frac{1}{1+\exp (-(T L-106.4) / 6.11)}\right)
$$

The $95 \%$ confidence interval ranged from 104.8 to $107.9 \mathrm{~cm}$ TL for $L_{50 \%}$ and from 5.09 to 7.33 for $\Phi$. The parameters of some species of the genus Rhizoprionodon are shown in table 3 .

\section{Reproductive seasonality}

Rhizoprionodon longurio reproduces annually off the continental coast of the Gulf of California. The presence of females with terminal embryos and vitellogenic oocytes was common from December to May. Embryos were observed in intermediate (December-February) and advanced (MarchMay) stages of development. The monthly mean size of individuals in these stages increased from December to May,

Table 2. Proportion of maturity stages and length for Rhizoprionodon longurio ( $\mathrm{TL}=$ total length).

Tabla 2. Proporción de estadios de madurez y longitud de Rhizoprionodon longurio (TL = longitud total).

\begin{tabular}{lrrcc}
\hline Stage & $\%$ & $\begin{array}{c}\text { Mean TL } \\
(\mathrm{cm})\end{array}$ & $\begin{array}{c}\text { Minimum } \\
\text { TL }(\mathrm{cm})\end{array}$ & $\begin{array}{c}\text { Maximum } \\
\text { TL }(\mathrm{cm})\end{array}$ \\
\hline Male & & & & \\
Neonate & 1.7 & 47.3 & 40.0 & 52.2 \\
Juvenile & 36.7 & 75.1 & 60.5 & 96.0 \\
Subadult & 30.7 & 97.3 & 87.2 & 107.0 \\
Adult & 30.9 & 103.9 & 93.0 & 112.7 \\
\hline Immature & 69.1 & 84.2 & 40.0 & 107.0 \\
Mature & 30.9 & 103.9 & 93.0 & 112.7 \\
\hline Female & & & & \\
Neonate & 1.6 & 48.1 & 41.0 & 51.4 \\
Juvenile & 23.1 & 73.1 & 61.1 & 82.0 \\
Subadult & 8.8 & 90.2 & 85.0 & 97.0 \\
Adult & 10.5 & 102.7 & 95.0 & 114.5 \\
Pregnant & 39.8 & 112.3 & 90.4 & 129.0 \\
Postpartum & 16.2 & 103.2 & 90.0 & 117.0 \\
\hline Immature & 33.5 & 76.4 & 41.0 & 97.0 \\
Mature & 66.5 & 108.6 & 90.0 & 129.0 \\
\hline
\end{tabular}

$$
M L=\left(\frac{1}{1+\exp (-(L T-106.4) / 6.11)}\right)
$$

El intervalo de confianza de 95\% fluctuó entre 104.8 y $107.9 \mathrm{~cm}$ LT para la $L_{50 \%}$ y entre 5.09 y 7.33 para $\Phi$. En la tabla 3 se muestran los parámetros de algunas especies del género Rhizoprionodon.

\section{Estacionalidad reproductiva}

Rhizoprionodon longurio se reproduce anualmente en la costa continental del Golfo de California. La presencia de hembras con embriones terminales y ovocitos vitelogénicos desarrollados fue común de diciembre a mayo. Los embriones se encontraron en estadios de desarrollo intermedio (diciembre-febrero) y avanzado (marzo-mayo). El promedio mensual de la talla de individuos en estos estadios fue ascendente de diciembre a mayo y no se encontraron hembras con embriones pequeños, lo cual confirma la ocurrencia de un solo proceso de gestación durante este periodo. La temporada de nacimiento fue de abril a julio, siendo junio el mes

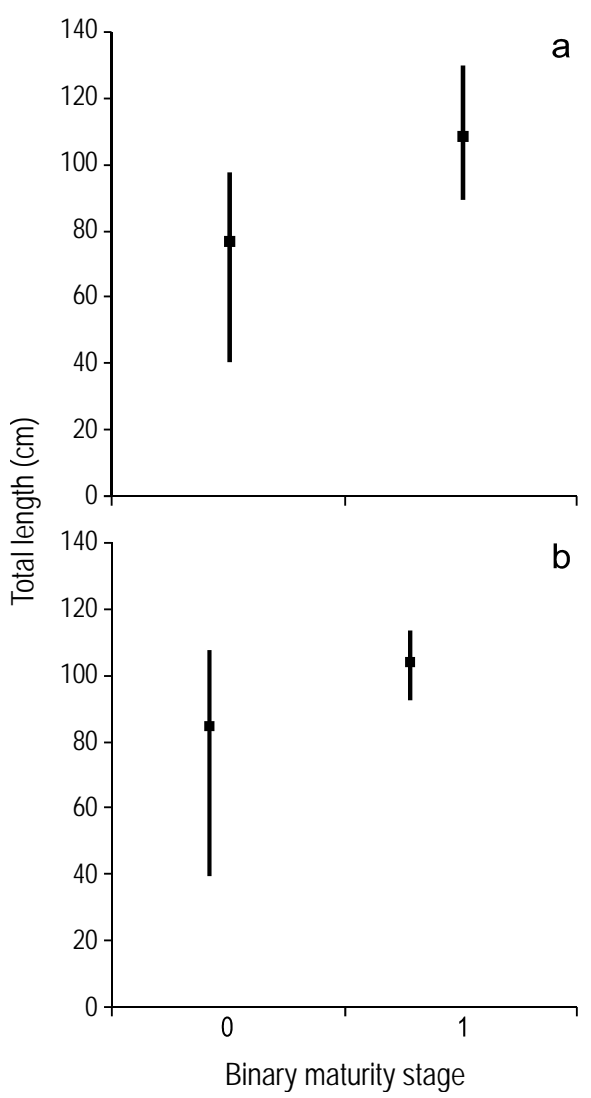

Figure 4. Size structure by binary maturity stage $(0=$ immature, $1=$ mature) of (a) female and (b) male Rhizoprionodon longurio in the Gulf of California.

Figura 4. Estructura de tallas por estadio binario de madurez ( 0 = inmaduro, 1 = maduro $)$ de (a) hembras y (b) machos de Rhizoprionodon longurio en el Golfo de California. 


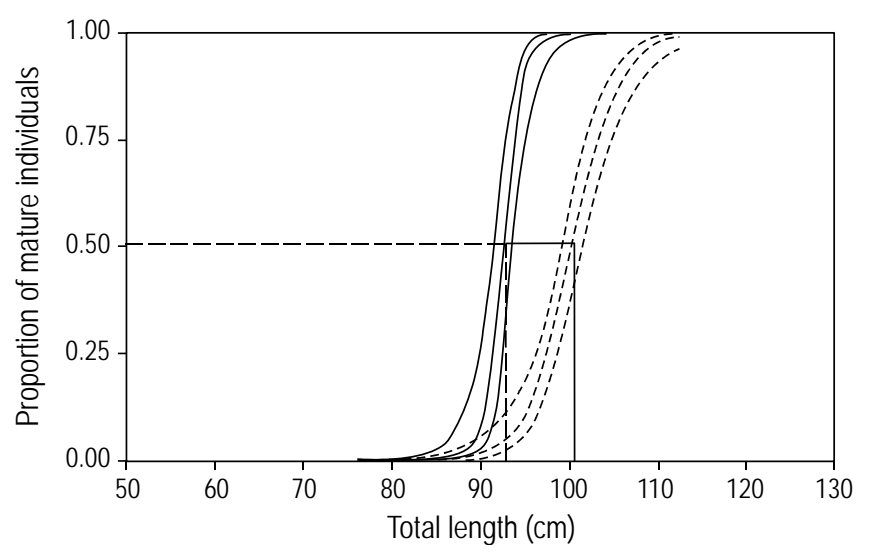

Figure 5. Maturity ogives showing the proportion of male (-) and female (---) mature individuals of Rhizoprionodon longurio in the Gulf of California.

Figura 5. Ojivas de madurez que muestran la proporción de individuos maduros para machos (-) y hembras (---) de Rhizoprionodon longurio en el Golfo de California.

and females with small embryos were not found, confirming the occurrence of only one gestation period. The birthing season was from April to July, with June being the main month and the beginning of a new reproductive period and gestation of a new litter. In neonates, the umbilical scar was observed until August.

\section{Discussion}

Information on size at sexual maturity is important in studies examining the reproductive cycle of sharks (Mollet et al. 2000, Carlson et al. 2003, Goldman and Musick 2006) and rays (Bizzarro et al. 2007, Paesch and Oddone 2009), and is an important complement in demographic studies (Cortés 1998). Maturity ogives have been estimated for some large (Francis and Duffy 2005, Shoou-Jeng et al. 2007) and medium-size (Carlson et al. 2003) sharks of the family Carcharhinidae. Comparisons of length at maturity of several species of oceanic sharks have revealed differences in the length at which individuals of a population attain sexual maturity in different geographic regions (Francis and Duffy 2005, Goldman and Musick 2006). Age at maturity (and length at maturity) is a factor that influences the productivity of a species (Francis and Duffy 2005). Data on length at maturity for the genus Rhizoprionodon, represented by seven coastal species, have been described by a logistic model only for R. terraenovae (Carlson and Baremore 2003), R. lalandii (Motta et al. 2007, Andrade et al. 2008), and R. acutus (Henderson et al. 2006, Harry et al. 2010). In the present study, the smallest male and female $R$. longurio measured 93 and $90 \mathrm{~cm} \mathrm{TL}_{\text {flex }}$, respectively. Márquez-Farías et al. (2005) recorded males of $80-95 \mathrm{~cm} \mathrm{TL}_{\text {nat }}$ in a state of transition from immature to mature, the smallest mature male measuring $93 \mathrm{~cm} \mathrm{TL}_{\text {nat }}$ and the smallest pregnant females measuring $83-88 \mathrm{~cm} \mathrm{TL}_{\text {nat }}$, which is $7 \mathrm{~cm}$ less than that found principal y el inicio de un nuevo periodo reproductivo y la gestación de una nueva camada. En los recién nacidos la cicatriz umbilical se observó hasta el mes de agosto.

\section{DISCUSIÓN}

La información de la talla de madurez sexual es importante en el estudio del ciclo reproductivo de los tiburones (Mollet et al. 2000, Carlson et al. 2003, Goldman y Musick 2006) y rayas (Bizzarro et al. 2007, Paesch y Oddone 2009), y es un complemento significativo en los estudios demográficos (Cortés 1998). Las ojivas de madurez se han estimado para algunas especies de tiburón de talla grande (Francis y Duffy 2005, Shoou-Jeng et al. 2007) y talla moderada (Carlson et al. 2003) de la familia Carcharhinidae. La comparación de la longitud a la madurez de varias especies de tiburones oceánicos ha mostrado diferencias en la longitud a la cual los individuos de una población adquieren la madurez sexual en diferentes regiones de su ámbito geográfico (Francis y Duffy 2005, Goldman y Musick 2006). La edad a la madurez (y la longitud a la madurez) es un factor que influye la productividad de una especie (Francis y Duffy 2005). La información de la longitud a la madurez del género Rhizoprionodon, que consiste en siete especies costeras, ha sido descrita por el modelo logístico sólo para $R$. terraenovae (Carlson y Baremore 2003), R. lalandii (Motta et al. 2007, Andrade et al. 2008) y R. acutus (Henderson et al. 2006, Harry et al. 2010). En este estudio la hembra y el macho de $R$. longurio de menor tamaño midieron 93 y $90 \mathrm{~cm}$ LT $_{\text {flex }}$, respectivamente. Márquez-Farías et al. (2005) registraron machos de 80-95 $\mathrm{cm} \mathrm{LT}_{\text {nat }}$ en un estadio de transición de inmadurez a madurez; el macho maduro más pequeño midió $93 \mathrm{~cm}$ de $\mathrm{LT}_{\text {nat }} \mathrm{y}$ las hembras preñadas más pequeñas midieron $83-88 \mathrm{~cm} \mathrm{LT}_{\text {nat }}, 7 \mathrm{~cm}$ más pequeñas que las encontradas en el presente estudio. Sin embargo, los resultados de los dos estudios de ambos sexos son consistentes debido a la ligera diferencia entre la $\mathrm{LT}_{\text {flex }}$ y la $\mathrm{LT}_{\text {nat }}$. Datos recientes de $R$. longurio de los golfos de California y Tehuantepec indican que los machos y hembras alcanzan la $L_{50 \%}$ a los 82 y $80 \mathrm{~cm}$ $\mathrm{LT}_{\text {nat }}$, respectivamente (Mejía-Salazar 2007).

Las especies del género Rhizoprionodon se mantienen en un intervalo de longitud máxima que va de $69 \mathrm{~cm}$ (R. taylori, Simpfendorfer 1993) a $135 \mathrm{~cm} \mathrm{LT} \mathrm{flex}_{\text {fle }}(R$. longurio, este estudio). La longitud media a la madurez para machos y hembras de $R$. longurio fue de 101 y $92 \mathrm{~cm} \mathrm{LT}_{\text {flex }}$, respectivamente. Estos valores son los más elevados intragenéricamente, seguidos de los obtenidos para $R$. acutus del noreste de Australia (74 y $78 \mathrm{~cm} \mathrm{LT}_{\text {flex }}$ para machos y hembras, respectivamente; Harry et al. 2010). El porcentaje relativo de la longitud a la madurez con base en la $\operatorname{LT}_{\text {flex }}$ (PRLM) de $R$. longurio fue $84 \%$ para los machos y $67 \%$ para las hembras. El PRLM en los machos de R. longurio es similar al de los machos de otras especies de tamaño moderado como Carcharhinus isodon $(89 \%$, con una edad de madurez 


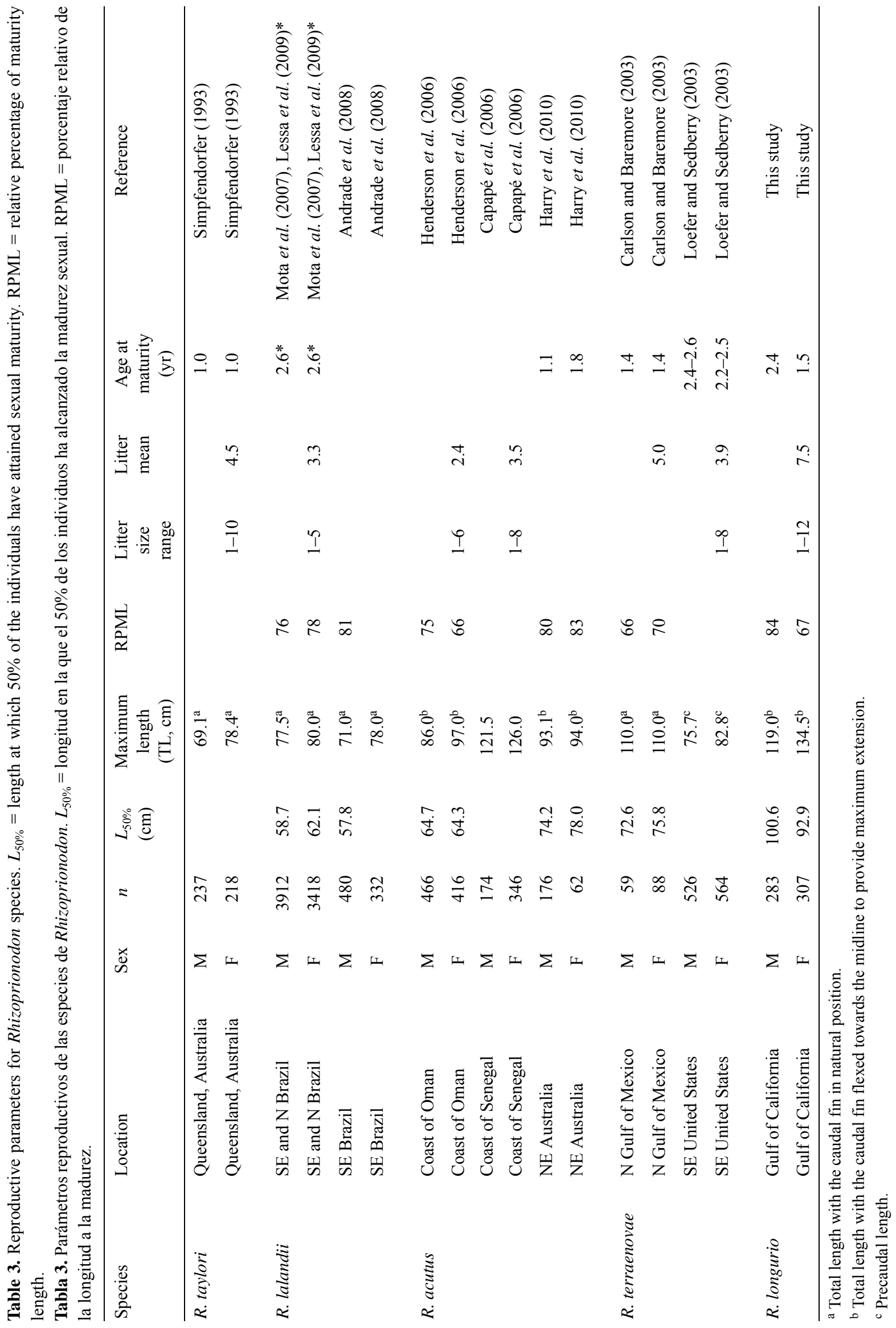


in our study. Nonetheless, the results obtained in both studies for both sexes are consistent because of the slight difference between $\mathrm{TL}_{\text {flex }}$ and $\mathrm{TL}_{\text {nat }}$. In a recent study on $R$. longurio from the gulfs of California and Tehuantepec, the $L_{50 \%}$ for males and females was estimated at 82 and $80 \mathrm{~cm} \mathrm{TL}$ nat, respectively (Mejía-Salazar 2007).

Maximum lengths reported for species of the genus Rhizoprionodon fall within a range of $69 \mathrm{~cm}$ (R. taylori, Simpfendorfer 1993) to $135 \mathrm{~cm} \mathrm{TL}_{\text {flex }}$ ( $R$. longurio, this study). Mean length at maturity for $R$. longurio males was $101 \mathrm{~cm}$ and for females, $92 \mathrm{~cm} \mathrm{TL}$ flex . Intragenerically, these are the highest values, followed by those obtained for $R$. acutus from northeastern Australia (74 and $78 \mathrm{~cm} \mathrm{TL}$ flex for males and females, respectively; Harry et al. 2010). The relative percentage of maturity length (RPML) based on $\mathrm{TL}_{\text {flex }}$ of $R$. longurio was $84 \%$ for males and $67 \%$ for females. The RPML for male $R$. longurio is similar to that of males of other medium-size species such as Carcharhinus isodon ( $89 \%$, with an age of maturity of $\sim 3.9 \mathrm{yr}$; Carlson et al. 2003). In contrast, the RPML for female $R$. longurio is one of the lowest of the genus and almost the same as that reported for R. acutus from the coast of Oman (Henderson et al. 2006) (table 2). The RPML between male and female $R$. longurio is very different from that of other small-size species of the order Carcharhiniformes like Mustelus asteria, M. mustelus, and M. schmitti, for which the values are similar between sexes: $75 \%$ and $78 \%$ (Farrell et al. 2010), $67 \%$ and $71 \%$ (Saïdi et al. 2008), and 70\% and 68\% (Segura and Milessi 2009) for males and females, respectively.

The 16-cm difference in maximum $\mathrm{TL}_{\text {flex }}$ of male and female $R$. longurio is the highest between sexes of the different species of the genus. This difference is of $9 \mathrm{~cm}$ for R. taylori (Simpfendorfer 1993), the smallest species of the genus, and of $7 \mathrm{~cm}$ for R. lalandii from southeastern Brazil (Andrade et al. 2008). Unlike other shark species whose females mature at a larger size than males (Pratt and Casey 1983, Cliff et al. 1990, Goldman and Musick 2006), $R$. longurio males mature at a greater length and age than females. On the other hand, population modeling indicates that shark species that mature at an early age have a greater capacity to recover from exploitation than those that mature at a later age (Smith et al. 1998). Our reproductive estimates for $R$. longurio were made using a representative sample size and appropriately covering all the stages, except that of female subadults $(n=27,8.8 \%)$. Subadults of other Rhizoprionodon species are rarely caught (Thorpe et al. 2004). In the Gulf of Mexico, female R. terraenovae are rarely captured because of the vast geographical segregation that exists between sexes after maturation and because of the influence of environmental conditions (Parsons and Hoffmayer 2005), particularly temperature and dissolved oxygen concentration, which according to Parsons and Carlson (1998) can have an immediate impact on the distribution and reproductive activity patterns. With an average of 7.5 pups per female, $R$. longurio has the highest de 3.9 años; Carlson et al. 2003). En contraste, el valor del PRLM de las hembras de $R$. longurio es uno de los más bajos del género y casi igual al registrado para $R$. acutus de la costa de Oman (Henderson et al. 2006) (tabla 2). El PRLM entre los sexos de $R$. longurio es muy diferente a otras especies de tamaño pequeño del orden Carcharhiniformes como Mustelus asteria, M. mustelus y M. Schmitti, cuyos valores de PRLM son muy cercanos entre sexos: $75 \%$ y $78 \%$ (Farrell et al. 2010 ), $67 \%$ y $71 \%$ (Saïdi et al. 2008), y $70 \%$ y $68 \%$ (Segura y Milessi 2009) para machos y hembras, respectivamente.

La diferencia de $16 \mathrm{~cm}$ entre la $\mathrm{LT}_{\text {flex }}$ máxima de machos y hembras de $R$. longurio es el valor más alto entre los sexos de las distintas especies del género. Esta diferencia es de $9 \mathrm{~cm}$ para $R$. taylori (Simpfendorfer 1993), la especie más pequeña del género, y de $7 \mathrm{~cm}$ para $R$. lalandii del sureste de Brasil (Andrade et al. 2008). Contrario a algunas especies de tiburón cuyas hembras maduran a un tamaño mayor que los machos (Pratt y Casey 1983, Cliff et al. 1990, Goldman y Musick 2006), los machos de $R$. longurio maduran a una mayor longitud y edad que las hembras. Por otra parte, la modelación de poblaciones indica que las especies de tiburón que maduran a una edad temprana tienen una mayor capacidad de recuperarse de la explotación que las especies que maduran a una edad mayor (Smith et al. 1998). Las estimaciones reproductivas de $R$. longurio en el presente estudio se hicieron con un tamaño de muestra representativo y cubren apropiadamente todos los estadios, excepto el de las hembras subadultas $(n=27,8.8 \%)$. Los subadultos de otras especies de Rhizoprionodon son rara vez capturados (Thorpe et al. 2004). En el Golfo de México las hembras de R. terraenovae son rara vez recolectadas debido a la existencia de segregación geográfica extrema entre los sexos después de la maduración y por la influencia de las condiciones ambientales (Parsons y Hoffmayer 2005), particularmente de la temperatura y concentración de oxígeno disuelto que, según Parsons y Carlson (1998), pueden tener un impacto inmediato en los patrones de distribución y actividad reproductiva. Con un promedio de 7.5 crías por hembra, $R$. longurio tiene la más alta productividad de crías del género a la fecha. La longitud máxima de $R$. terraenovae es de $110 \mathrm{~cm} \mathrm{LT}_{\text {nat }}$ y tiene 5.0 crías por hembra (Carlson y Baremore 2003); la de R. acutus (costa de Senegal) es de $126 \mathrm{~cm} \mathrm{LT}_{\text {nat }}$ (Capapé et al. 2006), muy próxima a la longitud máxima de $R$. longurio, y tiene 3.5 crías por hembra, un valor promedio muy bajo si se compara con la longitud máxima de esta especie. Rhizoprionodon longurio y $R$. taylori se aparean en verano y diferentes poblaciones de $R$. lalandii, $R$. acutus y $R$. terraenovae presentan sus periodos de apareamiento en primavera o verano. La reproducción anual es común en el género Rhizoprionodon (Simpfendorfer 1992, Capapé et al. 2006, Motta et al. 2007), y $R$. longurio presenta un ciclo anual de reproducción bien definido en la costa continental del Golfo de California. Durante los seis meses que dura la temporada de pesca de tiburón se encontraron los distintos estadios de la especie, lo que confirma que $R$. longurio utiliza esta región como un 
known productivity of pups of the genus. Rhizoprionodon terraenovae has a maximum length of $110 \mathrm{~cm} \mathrm{TL}$ nat and produces 5.0 pups per female (Carlson and Baremore 2003), whereas $R$. acutus (coast of Senegal) has a maximum length of $126 \mathrm{~cm} \mathrm{TL}_{\text {nat }}$ (Capapé et al. 2006), similar to that of $R$. longurio, and produces 3.5 pups per female, a very low average value when compared to the maximum length of this species. Rhizoprionodon longurio and $R$. taylori mate in summer, while different stocks of $R$. lalandii, $R$. acutus, and $R$. terraenovae mate in spring or summer. Annual reproduction is common in the genus Rhizoprionodon (Simpfendorfer 1992, Capapé et al. 2006, Motta et al. 2007), and R. longurio presents a well-defined annual reproductive cycle along the continental coast of the Gulf of California. The different maturity stages were found during the six months of the shark fishing season, confirming that $R$. longurio uses this region as a birthing, breeding, and feeding ground. Analysis of biological parameters and the proportion of maturity stages revealed changes in these parameters in $R$. terraenovae during a relatively short period of time (20 years), probably due to densodependent factors (Carlson and Baremore 2003). Contrary to the early sexual maturation of $R$. longurio and the high capacity of small-size species to recover from exploitation, demographic analyses suggest that the population of $R$. terraenovae from the Gulf of Mexico can be very vulnerable to fishing pressure (Cortés 1995, Márquez-Farías and Castillo-Géniz 1998), whereas $R$. taylori has one of the highest $r$ values obtained for any shark species (Simpfendorfer 1999). The immature individuals of $R$. longurio constituted $50 \%$ of the sample. This percentage is very low compared with the $80-90 \%$ recorded for $R$. terraenovae (MárquezFarías and Castillo-Géniz 1998); however, it has been shown that commercial exploitation based on immature individuals is not recommended for this species, since $R$. terraenovae is more vulnerable to recruitment overfishing than to growth overfishing (Gallucci et al. 2006). Hence, after three decades of exploitation in the Gulf of California, preventive management measures should be established for $R$. longurio until a proper demographic study is conducted. The strategy for the rational use and conservation of this species must include the protection of birthing grounds from April to July, the protection of juvenile and subadult nursery grounds from July to December (in the areas detected in the present study), and the use of longlines as the only authorized fishing gear. This information must complement that included in Official Mexican Norm 029, "Responsible shark and ray fishing. Specifications for their exploitation".

A major preoccupation in sustainable shark management is the increase in commercial landings worldwide. Evidence shows that in the Gulf of California, stocks of large-size sharks are overfished off the coast of Sonora and that artisanal fleets target the populations of small elasmobranchs (Bizzarro et al. 2009). As R. longurio is one of the most important species of the Sinaloan artisanal fishery (CorroEspinosa and Hernández-Carvallo 2002), it is important to área de nacimiento, apareamiento y alimentación. El análisis de los parámetros biológicos y la proporción de estadios de madurez han revelado la existencia de cambios en estos parámetros en $R$. terraenovae, en un periodo de tiempo relativamente corto (20 años), probablemente debido a factores denso-dependientes (Carlson y Baremore 2003). Contrario a la temprana maduración sexual de $R$. longurio y a la alta capacidad de las especies de tamaño pequeño para recuperarse de la explotación, los análisis demográficos sugieren que la población de $R$. terraenovae del Golfo de México puede ser muy vulnerable a la presión pesquera (Cortés 1995, Márquez-Farías y Castillo-Géniz 1998), mientras que $R$. taylori presenta uno de los valores más altos de $r$ entre las especies de tiburón (Simpfendorfer 1999). Los organismos inmaduros de $R$. longurio constituyeron el $50 \%$ del muestreo. Este porcentaje es demasiado bajo comparado con el 80-90\% para R. terraenovae (Márquez-Farías y Castillo-Géniz 1998); sin embargo, se ha demostrado que la explotación comercial basada en individuos inmaduros no es recomendable en este género, debido a que $R$. terraenovae es más vulnerable a la sobrepesca por reclutamiento que a la sobrepesca por crecimiento (Gallucci et al. 2006). Así, con tres décadas de explotación en el Golfo de California, el aprovechamiento de $R$. longurio deberá ser manejado con un enfoque precautorio mientras no se realice un estudio demográfico adecuado. La estrategia de uso racional y conservación de esta especie debe incluir la protección de las áreas de nacimiento de abril a julio, la protección de áreas de crianza de jóvenes y subadultos de julio a diciembre (en las zonas detectadas en este trabajo) y el uso de las cimbras o palangres como únicas artes de pesca autorizadas. Esta información debe complementar a la existente en la Norma Oficial Mexicana 029, "Pesca responsable de tiburones y rayas. Especificaciones para su aprovechamiento".

Una preocupación considerable en el manejo sostenible de los tiburones es que actualmente sus capturas comerciales se incrementan alrededor del mundo. Existe evidencia de que en el Golfo de California las poblaciones de tiburones de gran talla han sido sobreexplotados en la costa de Sonora y que las flotas de embarcaciones menores orientan su esfuerzo a las poblaciones de elasmobranquios de talla pequeña (Bizzarro et al. 2009). Debido a que $R$. longurio es una de las especies más importantes en la pesca artesanal de Sinaloa (CorroEspinosa y Hernández-Carvallo 2002), es importante complementar sus parámetros reproductivos. La información en su historia de vida podrá predecir la productividad de la población en esta área y asegurar niveles apropiados para su explotación comercial.

Los tiburones ocupan niveles altos en la cadena trófica y controlan las poblaciones de sus presas, por lo que es importante que este equilibrio permanezca en el ecosistema marino. Por otra parte, también es importante que el aprovechamiento de este recurso se mantenga en niveles sostenibles, debido a que un gran número de comunidades pesqueras en Nayarit, Sinaloa y Sonora hacen uso de esta 
supplement its reproductive parameters. Information on its life history will allow us to predict the productivity of the stocks in the area and ensure the appropriate exploitation levels.

Sharks occupy a high position in the food chain and control the populations of their prey. It is therefore important that this equilibrium be maintained in the marine ecosystem. It is also important that the exploitation of this resource be maintained at sustainable levels, since many fishing communities in Nayarit, Sinaloa, and Sonora target this and other shark species when stocks are susceptible to fishing, and the landings of this fishery resource contribute, during the period from December to July, to the income of approximately ten thousand families in Sinaloa alone. With the enforcement of Official Mexican Norm 029 for the protection of the breeding and nursery grounds of $R$. longurio and other shark species exploited commercially by these communities, orientation towards other productive activities and fisheries diversification programs will have to be implemented.

\section{CONCLUSIONS}

Rhizoprionodon longurio is a commercially important species on the continental coast of the Gulf of California. Mean size was $90.3 \mathrm{~cm}$ TL for males and $97.8 \mathrm{~cm}$ TL for females, and mean sizes of juveniles and subadults were, respectively, 75.1 and $97.3 \mathrm{~cm}$ TL for males and 73.1 and $90.2 \mathrm{~cm}$ TL for females. Statistically significant differences were found between sexes. The logistic functions that described the proportion of mature males and females were $M L=1 /(1+\exp (-(T L-100.61)) / 2.57)$ and $M L=1 /(1+$ $\exp (-(T L-92.9)) / 1.08)$, respectively. This information can be used to recommend fishery management measures for the species. The birthing and nursery grounds of this species must be protected during the periods April-July and July-December, respectively.

\section{ACKNOWLEDGEMENTS}

This study was funded by the Mexican Council for Science and Technology (CONACYT, project No. 62546). The first author acknowledges receipt of a doctoral scholarship from CONACYT. We thank the local fishermen from Sonora and Sinaloa for allowing us to analyze their landings, as well as C Castillo-Castro and the students of the Centro de Estudios Tecnológicos del Mar No. 28 in Altata, Sinaloa, for their collaboration during the biological sampling. Thanks are also due to P Valdez-Ledón for helping us use R statistical software.

English translation by Christine Harris.

\section{REFERENCES}

Abdel-Aziz SH, Khalil AN, Andel-Maguid SA. 1993. Reproductive cycle of the common guitarfish Rhinobatos rhinobatos y otras especies de tiburón cuando las poblaciones son susceptibles para la pesca, y la captura de este recurso pesquero contribuye, en el periodo de diciembre a julio, con una parte importante de los ingresos económicos de aproximadamente 10 mil familias, únicamente para Sinaloa. Con la aplicación de la Norma Oficial Mexicana 029 para la protección de áreas de reproducción y crianza de $R$. longurio y de otras especies de tiburón explotadas comercialmente por estas comunidades, se deberán aplicar programas de diversificación de la pesca y una orientación hacia otras actividades productivas.

\section{CONCLUSiOnes}

Rhizoprionodon longurio es una especie con importancia económica en la costa continental del Golfo de California. La talla media fue de $90.3 \mathrm{~cm}$ LT para machos y $97.8 \mathrm{~cm}$ LT para hembras, mientras que la talla promedio de jóvenes y subadultos fue, respectivamente, 75.1 y $97.3 \mathrm{~cm}$ LT para machos y 73.1 y $90.2 \mathrm{~cm}$ LT para hembras. Se encontraron diferencias estadísticamente significativas entre sexos. La función logística que describió la proporción de machos maduros fue $M L=1 /(1+\exp (-(L T-100.61)) / 2.57)$, y la de hembras maduras fue $M L=1 /(1+\exp (-(L T-92.9)) / 1.08)$. La incorporación de esta información permitirá aportar información para recomendar medidas de manejo pesquero para la especie. Las áreas de nacimiento y crianza de esta especie deben ser protegidas en los periodos abril-julio y julio-diciembre, respectivamente.

\section{Agradecimientos}

Este estudio fue financiado por el Consejo Nacional de Ciencia y Tecnología (CONACYT, proyecto No. 62546). El primer autor fue beneficiario de una beca doctoral del CONACYT. Agradecemos a los pescadores locales de Sonora y Sinaloa su invaluable apoyo al permitirnos analizar sus capturas. Gracias a C Castillo-Castro y los estudiantes del Centro de Estudios Tecnológicos del Mar No. 28 de Altata, Sinaloa, por su colaboración en el muestreo biológico. Se agradece la asesoría de $\mathrm{P}$ Valdez-Ledón en el programa estadístico R.

(Linnaeus 1758), in Alexandria waters, Mediterranean Sea. Aust. J. Mar. Freshw. Res. 44: 507-517.

Anderson ED. 1990. Fishery models as applied to elasmobranch fisheries. In: Pratt HL, Gruber SH, Taniuchi $\mathrm{T}$ (eds.), Elasmobranchs as living resources: Advances in the biology, ecology, systematics, and the status of the fisheries. NOAA Tech. Rep. NMFS 90: 473-484.

Andrade AC, Silva-Junior LC, Vianna M. 2008. Reproductive biology and population variables of the Brazilian sharpnose shark Rhizoprionodon lalandii (Müller and Henle 1839) captured in coastal waters of southeastern Brazil. J. Fish. Biol. 72: $473-484$.

Bizzarro JJ, Smith WD, Márquez-Farías JF, Hueter RE. 2007. Artisanal fisheries and reproductive biology of the golden 
cownose ray, Rhinoptera steindachneri Evermann and Jenkis, 1891, in the northern Mexican Pacific. Fish. Res. 84: 137-146.

Bizzarro JJ, Smith WD, Márquez-Farías JF, Tyminski J, Hueter RE. 2009. Temporal variation in the artisanal elasmobranch fishery of Sonora, Mexico. Fish. Res. 97: 103-117.

Capapé C, Diatta Y, Diop M, Guélorget O, Vergne Y, Quignard JP. 2006. Reproduction in the milk shark, Rhizoprionodon acutus (Rüppell 1837)(Chondrichthyes: Carcharhinidae), from the coast of Senegal (eastern tropical Atlantic). Acta Adriat. 47: $111-126$.

Carlson JK, Baremore IE. 2003. Changes in biological parameters of Atlantic sharpnose shark Rhizoprionodon terraenovae in the Gulf of Mexico: Evidence for density-dependent growth and maturity? J. Mar. Freshw. Res. 54: 1-8.

Carlson JK, Cortés E, Bethea DM. 2003. Life history and population dynamics of the finetooth shark (Carcharhinus isodon) in the northeastern Gulf of Mexico. Fish. Bull. 101: 281-292.

Cliff G, Dudley SF, Davis B. 1990. Sharks caught in the protective gillnets off Natal, South Africa. 3. The shortfin mako, Isurus oxyrinchus (Rafinesque). S. Afr. J. Mar. Sci. 9: 115-126.

Compagno LJV. 1984. Sharks of the World. An annotated and illustrated catalogue of sharks species known to date. FAO Fisheries Synopsis No. 125, Vol. 4. Part 2. Carcharhiniformes. Rome, pp. 251-655.

Corro-Espinosa D, Hernández-Carvallo A. 2002. Tiburones y rayas de Sinaloa. In: Cifuentes-Lemus JL, Gaxiola-López J (eds.), Atlas de la Biodiversidad de Sinaloa. El Colegio de Sinaloa, Culiacán, México, pp. 291-299.

Cortés E. 1995. Demographic analysis of the Atlantic sharpnose shark, Rhizoprionodon terraenovae, in the Gulf of Mexico. Fish. Bull. 93: 57-66.

Cortés E. 1998. Demographic analysis as an aid in shark stock assessment and management. Fish. Res. 39: 199-208.

Cortés E. 2004. Life history patterns, demography, and population dynamics. In: Carrier JC, Musick JA, Heithaus MR (eds.), Biology of Sharks and their Relatives. CRC Press, New York, pp. 449-469.

Farrell ED, Mariani S, Clarke MW. 2010. Reproductive biology of the starry smooth-hound shark Mustelus asterias: Geographic variation and implications for sustainable exploitation. J. Fish Biol. doi:10.1111/j.1095-8649.2010.02771.x.

Francis MP, Duffy C. 2005. Length maturity in three pelagic sharks (Lamna nasus, Isurus oxyrinchus, and Prionace glauca) from New Zealand. Fish. Bull. 103: 489-500.

Gallucci VF, Taylor IG, Erzini K. 2006. Conservation and management of exploited shark populations based on reproductive value. Can. J. Fish. Aquat. Sci. 63: 931-942.

Goldman KJ. 2004. Age and growth. In: Musick JA, Bonfil R (eds.), Elasmobranch Fisheries Management Techniques. Asia-Pacific Economic Cooperation Fisheries Working Group, pp. 97-132.

Goldman KG, Musick JA. 2006. Growth and maturity of salmon shark (Lamna ditropis) in the eastern and western North Pacific, and comments on back-calculation methods. Fish. Bull. 104: 278-292.

Harry AV, Simpfendorfer CA, Tobin AJ. 2010. Improving age, growth, and maturity estimates for aseasonally reproducing chondrichthyans. Fish Res. 106:393-403.

Henderson AC, McIlwain JL, Al-Oufi HS, Ambu-Ali A. 2006. Reproductive biology of the milk shark Rhizoprionodon acutus and the bigeye houndshark Iago omanensis in the coastal waters of Oman. J. Fish Biol. 68: 1662-1678.

Holden MJ. 1973. Are long-term sustainable fisheries for elasmobranchs possible? Rapp. P-V Reun. ICES J. Mar. Sci. 34: 161-168.
Holden MJ. 1974. Problems in the rational exploitation of elasmobranch populations and some suggested solutions. In: Harden-Jones FR (ed.), Sea Fisheries Research. Logos Press, London, pp. 117-137.

Lessa R, Santana FM, Da S, de Almeida Z. 2009. Age and growth of the Brazilian sharpnose shark, Rhizoprionodon lalandii and Caribbean sharpnose shark, $R$. porosus (Elasmobranchii, Carcharhinidae) on the northern coast of Brazil (Maranhão). Pan-Am. J. Aquat. Sci. 4: 532-544.

Loefer JK, Sedberry GR. 2003. Life history of the Atlantic sharpnose shark (Rhizoprionodon terraenovae) (Richardson, 1836) off the southeastern United States. Fish. Bull. 101: 75-88.

Márquez-Farías JF, Castillo-Géniz JL. 1998. Fishery biology and demography of the Atlantic sharpnose shark, Rhizoprionodon terraenovae, in the southern Gulf of Mexico. Fish. Res. 39: $183-198$.

Márquez-Farías JF, Corro-Espinosa D, Castillo-Géniz JL. 2005. Observations on the biology of the Pacific sharpnose shark (Rhizoprionodon longurio, Jordan and Gilbert 1882), captured in southern Sinaloa, Mexico. J. Northw. Atl. Fish. Sci. 35: $107-114$.

Mejía-Salazar LA. 2007. Biología reproductiva del cazón bironche, Rhizoprionodon longurio (Jordan y Gilbert 1882) en el Pacífico mexicano. M.Sc. thesis, Instituto Politécnico Nacional, Centro Interdisciplinario de Ciencias Marinas, La Paz, BCS, México. $67 \mathrm{pp}$.

Mollet HF, Cliff G, Pratt HL, Stevens JD. 2000. Reproductive biology of the female shortfin mako, Isurus oxyrinchus Rafinesque, 1810, with comments on the embryonic development of lamnoids. Fish. Bull. 98: 299-318.

Motta FS, Namora RC, Gadig OBF, Braga FMS. 2007. Reproductive biology of the Brazilian sharpnose shark (Rhizoprionodon lalandii) from southeastern Brazil. ICES J. Mar. Sci. 64: 1829-1835.

Musick JA.1999. Ecology and conservation of long-lived marine animals. In: Musick JA (ed.), Life in the Slow Lane: Ecology and Conservation of Long-Lived Marine Animals. American Fisheries Society Symp. 23, Bethesda, MD, pp. 1-10.

Paesch L, Oddone MC. 2009. Size at maturity and egg capsule of the softnose skates Bathyraja brachyurops (Fowler 1920) and Bathyraja macloviana (Norman 1937) (Elasmobranchii: Rajidae) in the SW Atlantic $\left(3700^{\prime}-3930^{\prime}\right.$ S). J. Appl. Ichthyol. 25 (Suppl. 1): 66-71.

Parsons GR, Carlson JK. 1998. Physiological and behavioral responses to hypoxia in the bonnethead shark, Sphyrna tiburo: Routine swimming and respiratory regulation. J. Fish. Physiol. Biochem. 19: 189-196.

Parsons GR, Hoffmayer ER. 2005. Seasonal changes in the distribution and relative abundance of the Atlantic sharpnose shark Rhizoprionodon terraenovae in the north central Gulf of Mexico. Copeia 4: 914-920.

Pratt HL, Casey JG. 1983. Age and growth of the shortfin mako, Isurus oxyrinchus, using four methods. Can. J. Fish. Aquat. Sci. 40: 1944-1957.

Saïdi B, Bradaï MN, Bordaïn A. 2008. Reproductive biology of the smooth-hound shark Mustelus mustelus (L) in the Gulf of Gabès (south-central Mediterranean Sea). J. Fish Biol. 72: 1343-1354.

Segura AM, Milessi AC. 2009. Biological and reproductive characteristics of the Patagonian smoothhound Mustelus schmitti (Chondrichthyes, Triakidae) as documented from an artisanal fishery in Uruguay. J. Appl. Ichthyol. 25 (Suppl. 1): 78-82.

Shoou-Jeng J, Che-Tsung CH, Hsian-Hua L, Kwang-Ming L. 2007. Age, growth, and reproduction of silky sharks, Carcharhinus 
falciformis, in northeastern Taiwan waters. Fish. Res. 10: 78-85.

Simpfendorfer CA. 1992. Reproductive strategy of the Australian sharpnose shark, Rhizoprionodon taylori (Elasmobranchii: Carcharhinidae), from Cleveland Bay, northern Queensland. Aust. J. Mar. Freshw. Res. 43: 67-75.

Simpfendorfer CA. 1993. Age and growth of the Australian sharpnose shark, Rhizoprionodon taylori, from north Queensland, Australia. Environ. Biol. Fish. 36: 233-241.
Simpfendorfer CA. 1999. Mortality estimates and demographic analysis for the Australian sharpnose shark, Rhizoprionodon taylori, from northern Australia. Fish. Bull. 97: 978-986.

Smith S, Au DW, Show C. 1998. Intrinsic rebound potentials of 26 species of Pacific sharks. Mar. Freshwat. Res. 49: 663-678.

Thorpe T, Jensen CF, Mosser ML. 2004. Relative abundance and reproductive characteristics of sharks in southeastern North Carolina coastal waters. Bull. Mar. Sci. 74: 3-20.

Received January 2011;

accepted February 2011. 